\title{
Sand-lime composites with basalt fibers
}

\author{
Paulina Kostrzewa, ${ }^{*}$ and Anna Stępień
}

Kielce University of Technology, Faculty of Civil Engineering and Architecture, Department of Building Engineering Technologies and Organization, al. Tysiąclecia PP 7, 25-314 Kielce, Poland.

\begin{abstract}
The fibers are used to reinforce concrete prevent first of all the formation of microcracks and open cracks, increase the strength and resistance of concrete. They also used in the production of wall building materials such as autoclaved cellular concrete, ceramics or silicate. Literature shows positive effects of the use of basalt (aggregate and dust) as an addition to autoclaved sand-lime products and the chemical composition of basalt fibers is not significantly different from the chemical composition of the basalt itself. The addition of basalt fibers did not bring the expected results. The additive adversely affects the fragility of the product, compressive and tensile strength of the product as well as absorbability. This is related to the incorrect arrangement of fibers in the sand-lime matrix. It can not be unequivocally stated that the addition of basalt fibers has a negative effect on lime-sand products. Further attempts should be made to apply basalt fibers more efficiently and to consider how to properly distribute the elements in the matrix.
\end{abstract}

\section{Introduction}

The form of construction objects that we face every day is the result of many changes that have taken place in the development of building materials for centuries. Construction is one of the areas in which improvements are constantly being made. In the last decades, huge progress has been observed in the field of material engineering, especially in the field of building materials, which is associated with increasingly stringent building regulations but also the availability of new technologies for producing materials. [1]

The composites occupy a special place on the building materials market. Fiberreinforced composites are currently predominant due to their best mechanical and strength characteristics with a minimum weight. Fibers used to reinforce concrete prevent first of all the formation of microcracks and open cracks, increase the strength and resistance of concrete. The fibers are also used in the production of wall building materials such as autoclaved cellular concrete, ceramics or silicate. Composites with a ceramic matrix - CMC (Ceramic Matrix Composites) are developed to increase the fracture toughness of ceramic materials. [2]

Autoclaved sand-lime products belong to one of the most popular building materials used in housing construction. They are characterized by high compressive strength, good acoustic insulation and frost resistance [3-5]. Silicates, just like ceramics, are a fragile

\footnotetext{
*Corresponding author: pkostrzewa@tu.kielce.pl
} 
material, therefore studies are being carried out to improve this property. Guided by the positive effects of using fibers in concrete, the authors have attempted to apply fibers to autoclaved lime-sand products. Basalt fibers were selected for the tests because of their temperature resistance, the Young's cubic modulus and tensile strength, ecology, chemical composition and good price-performance ratio. Research has been undertaken to determine the effect of basalt fibers on the properties, microstructure and the fragility of sand-lime bricks.

\section{Materials and methods}

Basalt fibers are a $100 \%$ natural additive used primarily as reinforcement for concrete, however, other applications are sought for this material. During the production process of basalt fiber, the material obtains a fine-crystalline structure composed of minerals characterized by high hardness and resistance to acids and bases, with the exception of hydrofluoric acid. A valuable feature of basalt fibers is their resistance to abrasion. Basalt fiber also has a very high resistance to moisture, is unaffected by atmospheric factors and time as well as is not subject to oxidation which is extremely important considering the purpose of silicates [6]. In addition, the literature shows positive effects of the use of basalt (aggregate and dust) as an addition to autoclaved sand-lime products, which is also a prerequisite for the use of this type of fibers.

The chemical composition of basalt fibers is not significantly different from the chemical composition of the basalt itself as can be seen in Table 1.

Table 1. Chemical composition of basalt fiber.

\begin{tabular}{|c|c|c|c|c|c|c|c|}
\hline \multicolumn{1}{|c|}{ Ingredients [\% by volume $]$} \\
\hline $\mathrm{SiO}_{2}$ & $\mathrm{Al}_{2} \mathrm{O}_{3}$ & $\mathrm{CaO}$ & $\mathrm{Fe}_{2} \mathrm{O}_{3}+\mathrm{FeO}$ & $\mathrm{MgO}$ & $\left(\mathrm{Na}_{2} \mathrm{O}+\mathrm{K}_{2} \mathrm{O}\right)$ & $\mathrm{TiO}_{2}$ & Other \\
\hline $51,0-59,3$ & $14,6-18,3$ & $5,9-9,4$ & $9,0-14,0$ & $3,0-5,3$ & $3,6-5,2$ & $0,8-2,25$ & $0,09-0,13$ \\
\hline
\end{tabular}

Table 2. Comparison of basalt fibers with other popular types of fibers [7, 8].

\begin{tabular}{|c|c|c|c|c|}
\hline Parameters & Basalt fibers & Steel fibers & Polymer fibers & Glass fibers \\
\hline Density [t/mm $\left.{ }^{3}\right]$ & $1,7-2,65$ & 7,8 & $0,9-1,4$ & $1,8-2,6$ \\
\hline Length [mm] & $24-54$ & $8-60$ & $6-54$ & $4-40$ \\
\hline Diameter [ $\mu]$ & $12-18$ & $20-40$ & $12-34$ & $13-20$ \\
\hline Young's modulus [GPa] & $70-90$ & $190-210$ & $35-40$ & $60-70$ \\
\hline Tensile strength [Mpa] & $700-1680$ & $550-1100$ & $480-1320$ & $410-1180$ \\
\hline Elongation at break [\%] & $0,5-1,6$ & $0,5-3,5$ & $2,0-4,0$ & $3,7-4,5$ \\
\hline Hardness [Mosh scale] & 8,5 & 9 & $1-3$ & $5-7$ \\
\hline
\end{tabular}

Traditional sand-lime products are made of about $90 \%$ quartz sand, $7 \%$ lime and 3\% water. To obtain modified products, specially prepared basalt fibers with a length of $10 \mathrm{~mm}$ were used in a volume to sand-lime ratio [Tab 3]. Laboratory tests have shown that shorter fibers are better distributed in the sand-lime mixture and with their participation it was easier to form bars with dimensions of 40x40x160 mm. 
Table 3. The content of basalt fibers in the sand-lime matrix.

\begin{tabular}{|c|c|c|}
\hline Name & Sand-lime mass & Basalt fibers \\
\hline $\mathrm{N}$ & $1800 \mathrm{~g}$ & - \\
\hline WB 3 & $1800 \mathrm{~g}$ & $0,3 \%=5,4 \mathrm{~g}$ \\
\hline WB 6 & $1800 \mathrm{~g}$ & $0,6 \%=10,8 \mathrm{~g}$ \\
\hline WB 9 & $1800 \mathrm{~g}$ & $0,9 \%=16,2 \mathrm{~g}$ \\
\hline
\end{tabular}

The sample marked "N" refers to the traditional product, "WB 3", "WB 6", "WB 9" to composites with different content of basalt fiber. The fibers used in the tested composites have a diameter, the value of which varies from 12 to $18 \mu \mathrm{m}$ (Fig 1).

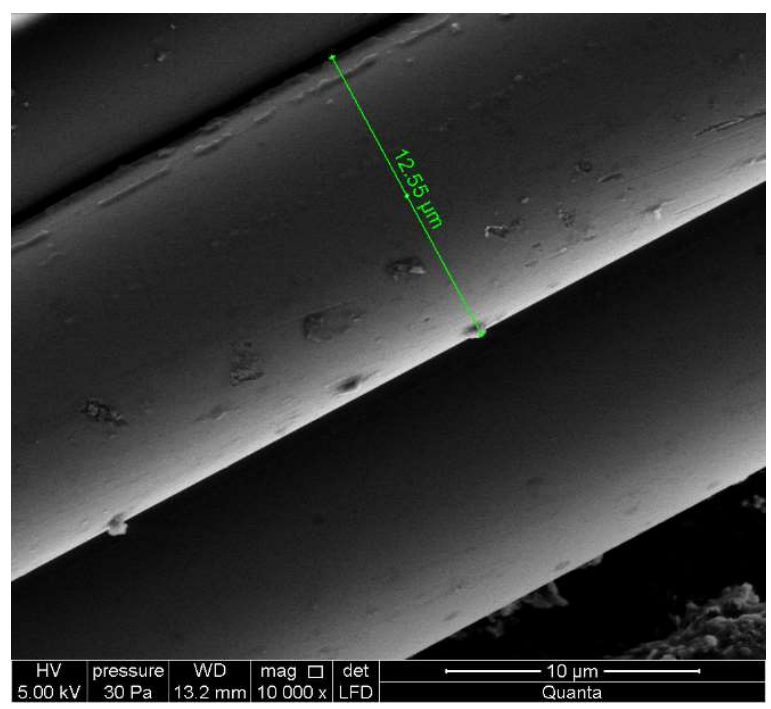

Fig. 1. Images of the microstructure of basalt fibers.

After promising laboratory tests, study were carried out in an industrial silicate plant,

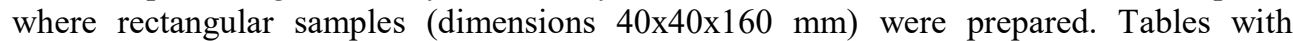
traditional composition and addition of basalt fibers were prepared. The procedure of mass preparation and sample formation proceeded in a fixed and repeatable manner. The basalt fibers were introduced into the raw material containing sand, quick lime and water, after the process of mass lime quenching. Then, the raw material mass was placed in molds and pressed at $20 \mathrm{MPa}$. The samples were then matured in an autoclave for 8 hours at $203^{\circ} \mathrm{C}$, 1.6 $\mathrm{MPa}$. The tests were carried out after 21 days from the time of disassembly of samples stored under air-dry conditions.

Tests of physical properties of the obtained plastics were carried out in accordance with the scope and methods given in standards relating to selected features: compressive strength [9], dry bulk density [10], water absorption [11]. Compressive strength was determined using the Tecnotest KC 300 press. The microstructure of materials obtained under hydrothermal conditions was examined by scanning microscopy. SEM-type Quanta 250 FEG with the EDS analyzer was used in the conducted research. 


\section{Results and discussion}

The results of physical and mechanical properties of limestone and sand products with the addition of basalt fibers and reference samples are presented in the following diagrams and photographs [Fig. 2-5]. The results presented are averaged values. Six samples consisted of each series.

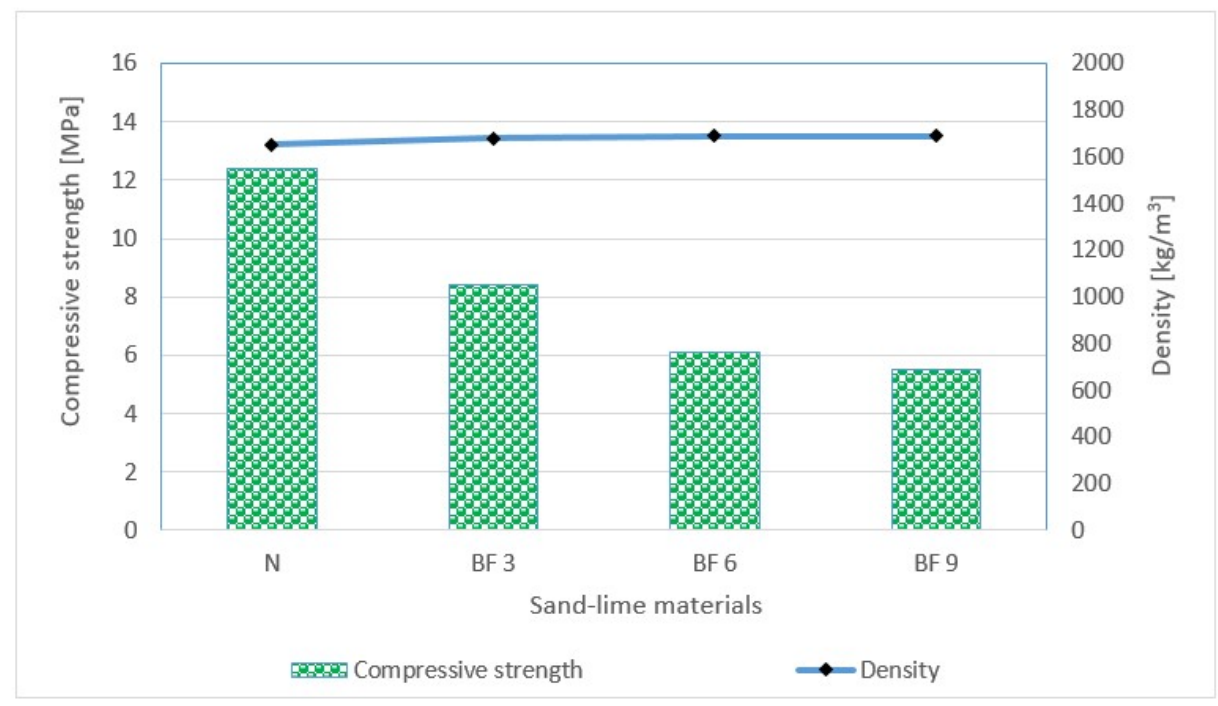

Fig. 2. Comparison of compressive strength and volume density results.

Samples with the addition of basalt fibers obtained lower compressive strengths compared to the reference sample. Strength decreases with the increase in the amount of fibers from about $35 \%$ to $50 \%$. The volume density did not change significantly due to the use of the additive, as shown in figure 2.

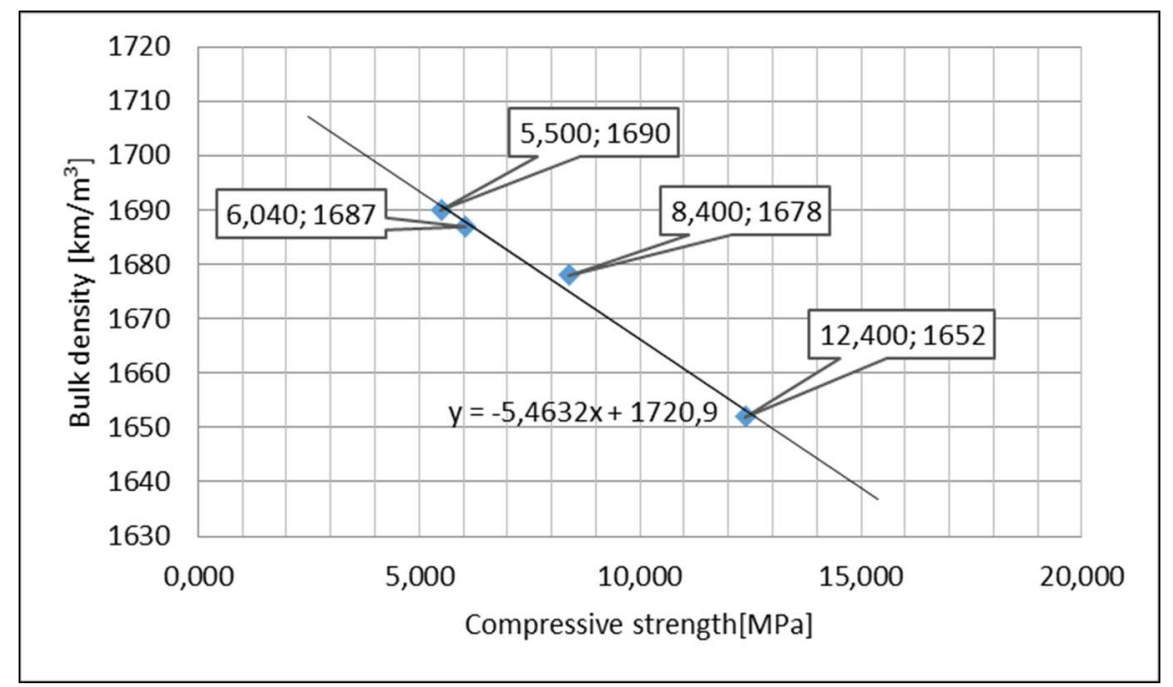

Fig. 3. Dependence of compressive strength and bulk density. 
The above figure (Figure 3) is a correlation diagram of bulk density and compressive strength. There is a strong negative correlation between compressive strength and bulk density, with a regression coefficient of approximately -5.5 and a correlation coefficient $|r| \approx 0.99$. The regression coefficient indicates how much the value of the $Y$ will change when the value of the $X$-feature changes by one unit. This measure determines the angle of inclination of the regression line with respect to the $X$ axis. The correlation graph shows the directly proportional dependence of the strength of the autoclaved products and their density.

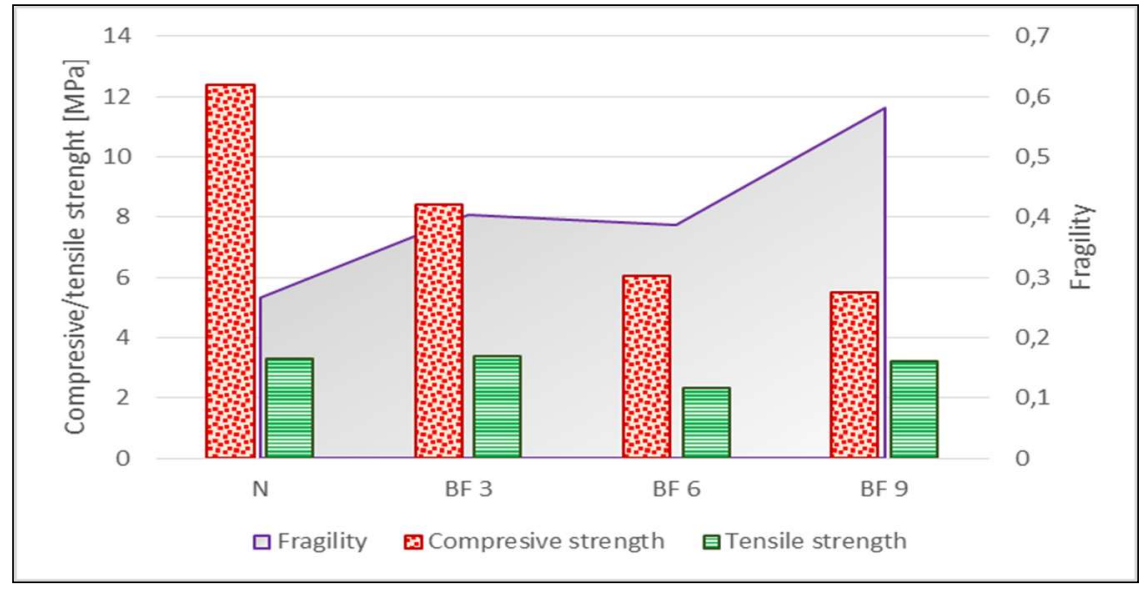

Fig. 4. Results of the fragility test of samples.

The criterion for the division of materials into brittle and elastic has no clear limit. It is assumed that if the ratio of tensile strength and compressive strength is less than $1 / 8$, the material is brittle. Analysis of the results of the fragility of the samples shows that the use of basalt fiber had an effect on improving the brittleness of the material from about 0.25 to almost 0.6 (Figure 4). However, this is an improvement resulting from the reduction of the compressive strength and the compensated values of compressive and tensile strength. Thus, no improvement in brittleness can be associated with the use of basalt fibers.

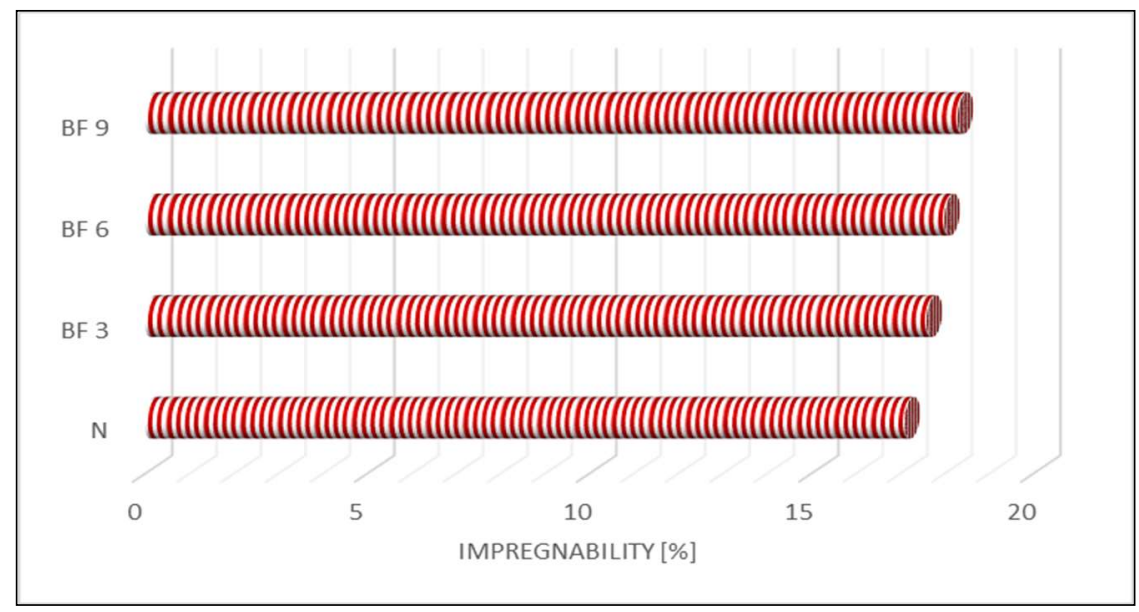

Fig. 5. List of absorbability results of a traditional sample and additions of basalt fibers.

Products modified with basalt fiber have greater absorbability than the traditional sample (Figure 5). With the increase in the amount of used basalt fiber, the amount of water 
that the sample absorbed increases (on average, for every $0.3 \%$ increase in the amount of additive in relation to the volume of the matrix, the absorbability increases by about $0.5 \%$ ).

The characteristic microstructure images of the analyzed fracture surfaces of the samples observed under the scanning microscope are shown in figures: 6 and 7.

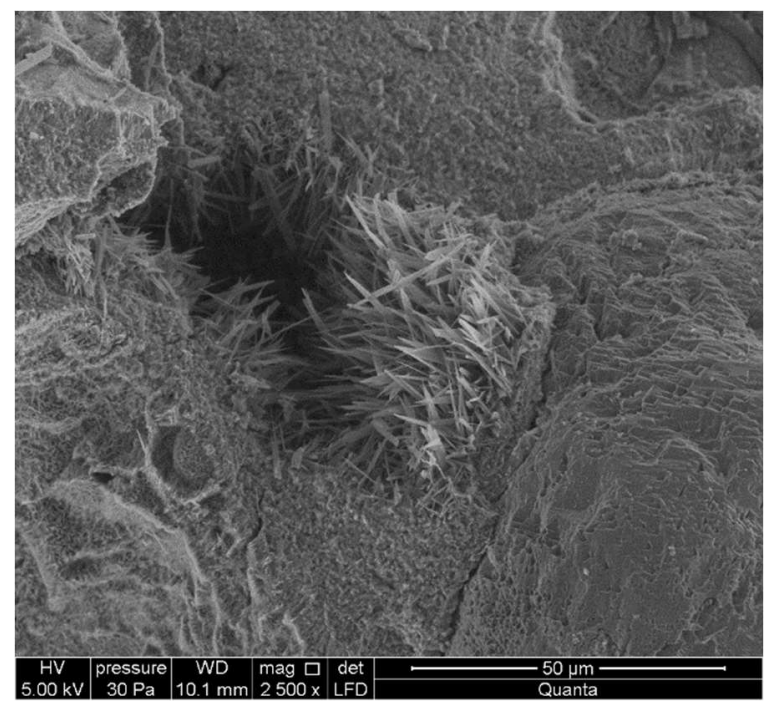

Fig. 6. Microstructure of a sample of a traditional silicate product.

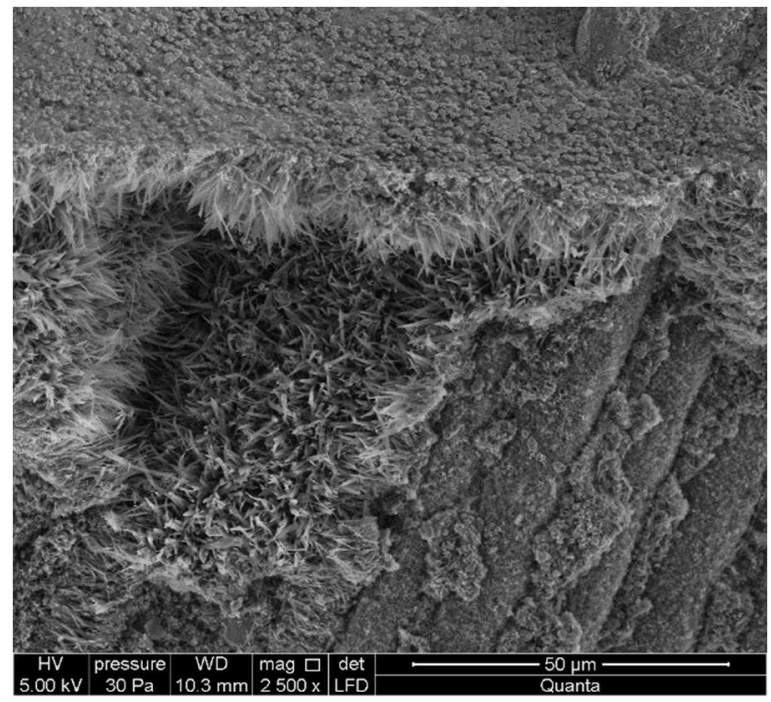

Fig. 7. Microstructure of a sample modified with basalt fibers.

In the reference sample (Figure 6), a fragment of the material partially covered with the spongy C-S-H phase and tobermoryt (appearing in the form of needles) is visible. In the modified samples, the C-S-H phase is also observed at the interface with aggregate and tobermorite crystals. The proportion of both phases is smaller compared to the reference sample, especially when it comes to the amount of tobermorite crystals formed, which is conditioned by the presence of aluminum. In the initial stage of aluminum autoclavation affects the solubility of silica, it causes the direct formation of the C-S-H phase and in the final stage of the tobermorite $[12,13]$. The picture (Figure 7) shows the C-S-H phase and 
smaller amounts of tobermorite crystals. In the sample with the addition of basalt fibers it is easy to distinguish their shape, it can be seen that at the interface of lime-sand matrix and fibers formed connections.

In the traditional production process of autoclaved silicate products, the synthesis products are usually amorphous $\mathrm{C}-\mathrm{S}-\mathrm{H}$ phase and crystalline tobermorite $\left(\mathrm{C}_{5} \mathrm{~S}_{6} \mathrm{H}_{5}\right)$ [14-17]. According to literature data, the strength of autoclaved plastics depends on the total content of both mineral phases $[18,19]$. This means that the effect of improving the strength characteristics can be achieved by providing optimal conditions for the course of synthesis reactions, and thus obtaining more of the mentioned phases. Such results can be obtained as a result of appropriate chemical or physical activation of the reacting components [20].

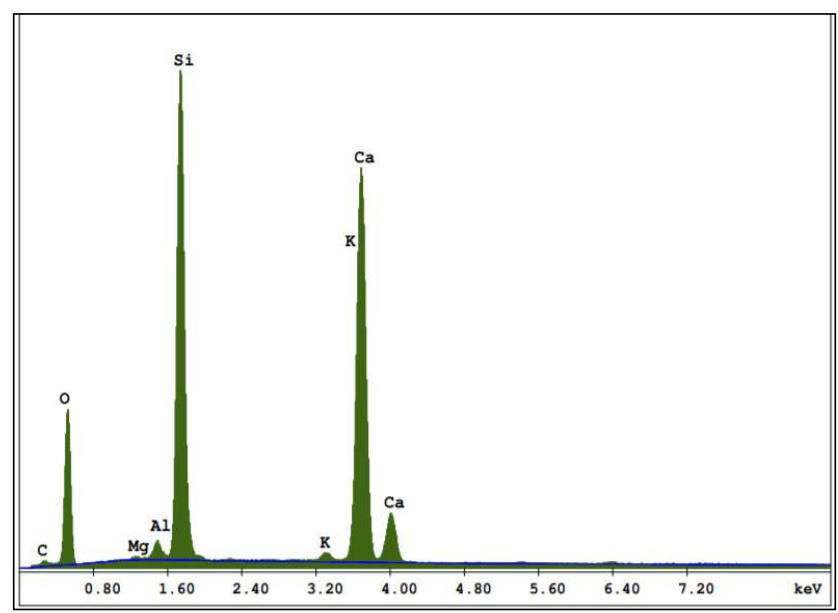

Fig. 8. EDS analysis for a traditional sample

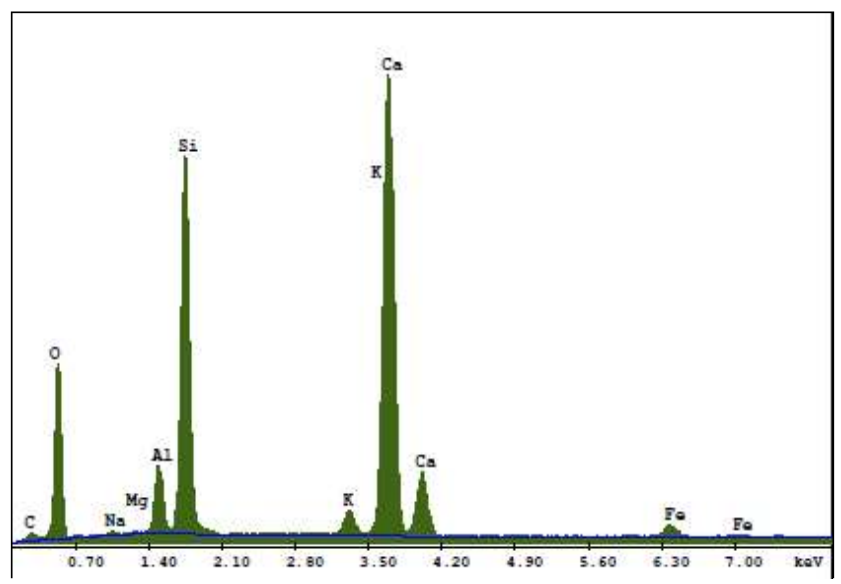

Fig. 9. EDS analysis for a sample with the addition of basalt fibers.

The EDS analysis confirms the increased content of aluminum and iron in the modified sample (figure 9). These elements negatively affect the course of reactions between $\mathrm{Ca}$ and $\mathrm{SiO}_{4}$.

The difference in the compressive strength and absorbability of the sample with the addition of basalt fibers and no additive is probably related to incorrect homogenization of the modified product components. In contrast to concrete, which is well workable (easily fills complex shapes, without a lot of work on compaction), the sand-lime mix has the 
consistency of moist sand. This significantly impedes the correct distribution of fibers in the matrix, resulting in clusters of fibers (Figures 10a and 10b). Places of density of fibers in the matrix cause an increase in porosity and weakness of the product structure which translates into lower strengths compared to traditional silicate. In connection with the above, the fiber length used $-1 \mathrm{~cm}$, also turns out to be ineffective.

a)

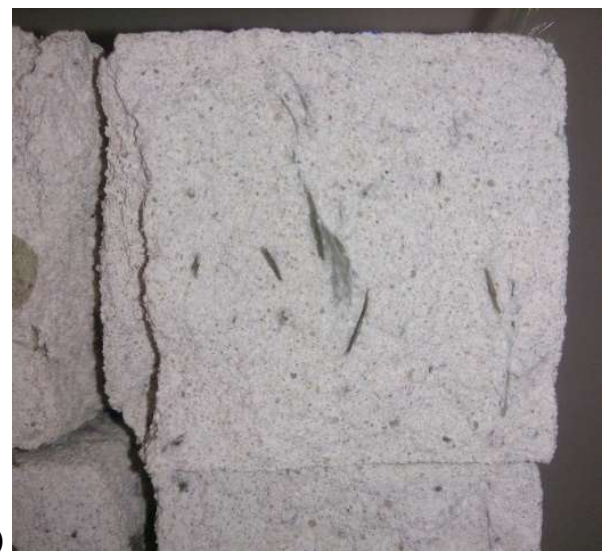

b)

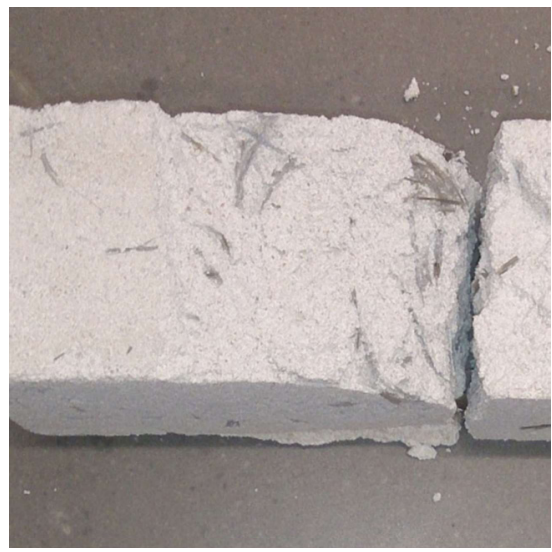

Fig. 10a/10b. Cross sections of samples modified with basalt fibers.

\section{Summary and conclusions}

Research studies show the influence of the addition of basalt fibers on the particular properties of lime-sand products. On their basis, several conclusions can be formulated. During research in an industrial plant, the addition of basalt fibers did not bring the expected effects in the form of improving the physical and mechanical properties. The additive adversely affects the fragility, compressive and tensile strength as well as absorbability of the product. This is related to the incorrect arrangement of fibers in the sand-lime matrix. In contrast to preliminary laboratory tests, which were promising, during the research at the industrial plant, the positive effects of the addition of basalt fibers could not be duplicated. The decisive factor here is production technology, whose radical change would be expensive and the current one does not allow to obtain an appropriate distribution of fibers in the mix. However, it can not be unequivocally stated that the addition of basalt fibers has a negative effect on lime-sand products. Further attempts should be made to apply basalt fibers more efficiently and to consider how to properly distribute the elements in the matrix. In addition, further testing with different fiber lengths and determining the optimal additive content are recommended.

\section{References}

1. J. Krassowska, A. Łapko, Przydatność stosowania nowoczesnych kompozytów fibrobetonowych w konstrukcjach budowlanych, Budownictwo i Inżynieria Środowiska 2, 1 (2011)

2. M. Fejdyś, M. Łandwijt, Włókna techniczne wzmacniające materiały kompozytowe, Techniczne Wyroby Włókiennicze, 2010

3. R. Dachowski, M. Nowek, Procedia Engineering, 161 (2016)

4. R. Dachowski, P. Kostrzewa Impact of polyethylene glycol on porosity and microstructure of sand-lime product, E3S Web of Conferences 10 (2016) 
5. A. Stępień, P. Kostrzewa, Autoclaved Sand-Lime Products with a Polypropylene Mesh Material Science and Egineering 245 (2017)

6. S. M. Dobosz, J Godziemski, M. Piasecki, Solidification of Metals and Alloys 1, 39 (1999)

7. M. Kozieł, Charakterystyka krajowych bazaltów region dolnośląskiego z przeznaczeniem na włókna amorficzne, Scientific Works of Institute of Glass, Ceramics Refractory and Construction Materials, 4 (2009)

8. T. Zych, Technical Transactions, 8-A (2010)

9. PN-EN 772-1+A1:2015-10E Methods of test for masonry units - Part 1: Determination of compressive strength

10. PN-EN 772-13:2001P Methods of masonry units - Part 13: Determination of net and gross dry density of masonry units (except for natural stone)

11. PN-EN 772-21:2011E Methods of test for masonry units - Part 21: Determination of water absorption of clay and calcium silicate masonry units by cold water absorption

12. G. Zapotoczna-Sytek, S. Balkovic, Autoclaved Aerated Concrete (2013)

13. R. Dachowski, S. Stępień, The Impact of Barium Aggregate on the Microstructure of Sand-Lime Products, Trans Tech Publications LTD (2011)

14. D. Kubatova, M. Bohac, R. Necas, The Effect of Mechanical Activation of Lime Putty on Properties of the Autoclaved Calcium Hydrosilicate Materials, 151 (2016)

15. S. Shaw, S. M. Clark, C. M. B. Henderson, Hydrothermal Formation of the Calcium Silicate Hydrates, Tobermorite $\left(\mathrm{Ca}_{5} \mathrm{Si}_{6} \mathrm{O}_{16}(\mathrm{OH})_{2} \cdot 4 \mathrm{H}_{2} \mathrm{O}\right)$ and Xonotlite $\left(\mathrm{Ca}_{6} \mathrm{Si}_{6} \mathrm{O}_{17}(\mathrm{OH})_{2}\right)$ : an in Situ Synchrotron Study, 167 (2000)

16. A. Hartmann, J. C. Buhl, K. Breugel, Structure and phase investigations on crystallization of 11 Å tobermorite in lime sand pellets, Cement Concrete Res., 37 (2017)

17. R. Dachowski, Z. Owsiak, Advanced Materials Research, 250-253 (2011)

18. J. M. Cren, J. R. L. Dyczek, H. F. W. Taylor, Cement Concrete Res. 2 (1972)

19. R. Dachowski, A. Stępień, Procedia Engineering, 21 (2011)

20. P. Gębarowski, K. Łaskawiec, M. Skoroniewska, Influence autoclaving on the properties of silicate materials Scienific Works of Institute of Ceramics and Building Materials, 20 (2015) 